\title{
THE INDEPENDENT LABOUR PARTY AND THE YORKSHIRE MINERS: THE BARNSLEY BY-ELECTION OF 1897*
}

The Independent Labour Party was formed early in 1893, at a time when its founders hoped that reformist, undogmatic Socialism would soon attract the support of large numbers of working men. This was a hope shared by others committed to a more rigorous Socialist ideology. Even Friedrich Engels, convinced that the formation of a political party sustained by the working class was the task of greatest importance, hailed the ILP as the body desired by the old members of the International of the 1860 's. ${ }^{1}$ But the early hopes were short-lived. Everyone of its twenty-eight candidates was defeated at the General Election of 1895 , even Keir Hardie, the party's leader, who had been elected at West Ham without Liberal opposition in 1892. Many of the candidates polled well, but the overall result was a deep disappointment. In four subsequent by-elections between May 1896 and October 1897, ILP candidates of proven ability, while finding considerable support among the electorate, finished last on each occasion, and the trend of election results grew worse rather than better. The ILP polled thousands of votes rather than the few hundreds of the Marxist body, the Social Democratic Federation, but this was small consolation. In terms of

* The Barnsley by-election of 1897 has nowhere been treated in detail in published works. It has been discussed in two doctoral theses: A. E. P. Duffy, MP, "The Growth of Trade Unionism in England from 1867 to 1906 in its political aspects" (London, 1956), pp. 578-88, and Robert Neville, "The Yorkshire Miners 1881-1926: A study in labour and social history" (Leeds, 1974), pp. 456-63. Both theses have contributed greatly to my understanding of the Yorkshire miners and their political attitudes. I am grateful to Dr Duffy for allowing me to photocopy the relevant pages of his thesis, and to Dr Neville for repeated and generous assistance over an extended period. I am grateful also to Professor John Saville, who suggested the topic and read and criticised a draft of this article. Finally, I am grateful to the National Union of Mineworkers in London and Barnsley, the Yorkshire Post and the Evening Post, and librarians of public, national and university libraries in Barnsley, Hull, Leeds, London, Sheffield and Wakefield, for their kind and indispensable assistance.

1 Henry Pelling, The Origins of the Labour Party, 1880-1900, 2nd ed. (London. 1965), p. 123 , note. 
membership and general party activity the years after 1895 also marked a regression. Gradually Hardie and his colleages became convinced that winning the workers to Socialism by means of the ILP alone was not a feasible strategy. There was no way, in the short term, to further the cause of independent labour without the adhesion of the non-Socialist trade unions. This inevitably meant the soft-pedalling of Socialism. Defeated as a separate force, the ILP was forced to accept the idea of an alliance with the trade unions, in the hope that any form of labour party would first become independent of the Liberals and eventually Socialist. ${ }^{2}$ The first assumption proved correct, the second on the whole incorrect, but it is difficult to see what other course could have been pursued at the time. Thus the years between 1895 and 1900, the vital pre-history of the Labour Party, were years which were to stamp it at its birth in 1900 as a party of practical trade unionists, fighting for limited aims, with a smattering of Socialists whose influence failed to dominate the party programme or strategy.

In this development the Barnsley by-election of 1897 played an important part. At Barnsley the ILP took on the Yorkshire Miners' Association, a body of great strength and self-confidence. The YMA was by far the most numerous and powerful constituent of the largest trade union in the country, the Miners' Federation of Great Britain, founded in 1889. In the absence of the miners of Durham and South Wales the 50,000 members affiliated by the YMA formed a third of the Federation's 148,562 members in $1897 . .^{3}$ The secretary of the YMA from its foundation in 1881 was Benjamin Pickard (1842-1904), president of the MFGB from its own inception. Edward Cowey (1839-1903), president of the YMA from 1881 until his death, and William Parrott (1843-1905), the YMA agent, were also members of the MFGB executive, further emphasising the Yorkshire influence within the Federation and the audacity of the ILP challenge. John Frith (1837-1904), the YMA financial secretary, was the fourth of the forceful quartet of Yorkshire leaders. ${ }^{4}$ The offices of the YMA were in Barnsley.

2 Ibid., pp. 173-74, 179-81; Stanley Pierson, Marxism and the Origins of British Socialism (Ithaca, 1973), ch. 9; G. D. H. Cole, British Working Class Politics 1832-1914 (London, 1941), pp. 268, 272-75; Kenneth Morgan, Keir Hardie: Radical and Socialist (London, 1975), pp. 90-98.

${ }^{3}$ MFGB, Annual Conference Report, 1897, p. 36; R. Page Arnot, The Miners (London, 1949), p. 393.

${ }^{4}$ See the biographies of each of these men in the Dictionary of Labour Biography, ed. by Joyce Bellamy and John Saville: Pickard, Cowey and Frith in Vol. I (1972), Parrott in Vol. II (1974). See also Neville, "The Yorkshire Miners", op. cit., biographical appendix. 
At the time of the election Barnsley town had a population of about 40,000 , and some 6,400 of the 14,805 voters in the constituency. The manufacture of linen, formerly a staple product, was in decline by the 1890 's, although some demand remained. The production of damasks and coarse cotton fabric had also declined, but glass bottles, wire, down quilts and paper were all made, and brewing had also developed. Coal, however, was the principal industry. Barnsley was the coal capital of Yorkshire, situated as it was among what were claimed to be the richest coalfields in the country, and over a quarter of the town's male workforce in 1901 were miners. The constituency itself covered some 65 square miles. The opening of new mines had resulted in a large increase in the population of neighbouring towns and villages. Most of the towns numbered between 2,000 and 6,000 in 1901, and many of them were more dependent upon coal than Barnsley itself. Nearly seventy per cent of the male workforce of Wombwell, the second-largest community with about 13,000 inhabitants, were miners, as were nearly two-thirds in the urban district of Darton, whose population, which comprised three communities, exceeded seven thousand. There were twenty-five polling districts in the constituency, most of them consisting of one or more towns or villages, but six were in Barnsley and two in Wombwell. Barnsley constituency, which outsiders tended to find shabby and unpleasing, was a predominantly working-class place. Only a little over a thousand of the voters owned their homes, the vast majority of the remainder being tenants who qualified for the vote as householders or occupiers. ${ }^{5}$ Ben Pickard claimed that over 10,000 miners in the division were paid-up members of the YMA, a fifth of the union's entire membership, and the number of voters who were miners was variously estimated at $7,000,8,000$ and $10,000 .^{6}$

The ILP, although stronger in parts of the West Riding than anywhere else in the country, had made little progress in the Yorkshire coalfield. It had

5 This description is drawn from Lodge's Barnsley \& District Almanack and Trades' Directory for 1898, unpaginated; The Barnsley Red Book, Almanack, and Directory, 1899, pp. 17-18, 123-35; Robinson's Barnsley Directory (1902), pp. 11, 173; Census of England and Wales, 1901, County of York; Area, Houses and Population [Cd 1107], pp. 9,71-79, 258, 260; Sheffield Daily Telegraph, 23 September and 29 October 1897; Labour Leader (hereafter LL), 9 October.

${ }^{6}$ Barnsley Chronicle (hereafter BC), 23 October 1897; Sheffield \& Rotherham Independent (hereafter S\&RI), 27 October; Pall Mall Gazette, 23 and 28 October. Roy Gregory, The Miners and British Politics 1906-1914 (London, 1968), p. 138, suggests that forty-six per cent of the voters in the Barnsley division were miners in about 1910, and if the anomalies of electoral law which bore harshly on working-class voters are borne in mind, 7,000 miner voters in 1897 would seem an approximately accurate figure. See also sources cited in note 53 . 
never put up a parliamentary candidate in an English mining constituency. Concerned by its weakness among miners, the party appointed a paid organiser in July 1896. The man appointed was Tom Taylor of Barnsley, a prominent member of the YMA who for nearly a year worked among the miners of Yorkshire and Durham, with briefer visits to Lancashire, Derbyshire and South Wales. In the summer or early autumn of 1896 Taylor formed a Barnsley branch of the ILP, which at the start of the by-election campaign in September 1897 had about forty members. A branch at Hemsworth, a mining community in the Barnsley division, which Taylor formed at about the same time seems never to have had more than a paper existence, for Barnsley itself was asserted to be the only place in the constituency where ILP meetings had been held. ${ }^{7}$ In fighting Barnsley the daunting task facing the ILP was to attempt an appeal to miner voters over the heads of their leaders in what Keir Hardie acknowledged to be "the very headquarters and centre of official Liberal-Labourism". ${ }^{8}$

Under favourable conditions the ILP was able to establish itself in collaboration with trade unionism. Where unions were well established, however, close Liberal links had usually developed. The adherence of trade unionists to Liberalism was particularly strong among miners. The leaders of the Yorkshire miners were among the most powerful and vocal of working-class Liberals. The Liberal Party claimed to stand for the right to vote, the right to form trade unions, the advance of popular education, the working man's means of obtaining elective office, and a measure of equality of opportunity which would reward those who practised self-help and weaken the caste-like social distinctions of late-Victorian England. Although these and other Liberal principles were rooted mainly in the demands of middle-class Radicals and Nonconformists, they won the support of trade unionists as well. As relatively well paid and privileged members of the working class, trade unionists tended to accept the Liberal view that manufacturers and workers shared common interests and belonged alike to the "industrious" section of the community. If religious they too tended to be Nonconformists, and Nonconformity, which sank deep roots in socially isolated mining communities, stressed individualism and class harmony between employers and employed. Thus the common

7 ILP, NAC minutes, 22 April, 3 July and 1 October 1896, 5 January and 21 April 1897, British Library of Political and Economic Science; Leeds Mercury (hereafter LM), 22 September 1897; Barnsley Independent (hereafter BI), 2 October; Standard, 23 October; LL, 6 November; I.L.P. News, November; ILP, Annual Conference Report, 1897, p. 7; ibid., 1898, p. 19. Barnsley delegates attending the annual conference in April 1897 represented 60 members, ibid., 1897, p. 3.

8 LL, 2 October 1897. 
enemy was seen as the "parasitic" hereditary landed class, to which large mineral royalties were paid, and its close ally the Church of England - twin bastions of a hierarchical society. The tenets of Liberalism, moderate though they appeared to Socialists, were regarded by many Conservatives as dangerously novel and Radical, and by miners and other working men as satisfyingly advanced.

In fact the popular image was by no means exact, for not only was the Liberal Party as a whole much less Radical than many of its supporters believed, but as politics became increasingly involved with social questions the Radicalism of the older school became increasingly outmoded. Similarly, as trade unions grew in numbers and strength Liberal working men frequently found themselves confronting Liberal employers. However, political beliefs and loyalties once formed were not easily broken. Moreover, in the 1890's the party was becoming more sympathetic to social reform and more responsive to labour pressure. The aged Gladstone symbolised the Liberal-Labour alliance, and although he was never an enthusiastic proponent of social or labour legislation, he appears to have manifested in his final years a growing understanding of the needs and demands of labour. His changed perspective was shown in a Second Reading speech in 1893, in which he gave a carefully qualified support to a bill whose purpose was to enact the miners' cherished legal eight-hour day. Under these circumstances Yorkshire miners in the 1890's, however militant in industrial disputes, remained on the whole satisfied with the Liberal politics of class collaboration. ${ }^{9}$ Conservatism was ruled out for most miners as for most other trade unionists, for its considerable achievements in political and social reform were outweighed by its associations with a privileged class in both church and state. There was, however, a considerable minority of Conservative miners. In Staffordshire and in Lancashire, with its strong working-class Conservative tradition, Conservative miners may have been a virtual or an actual majority, and

9 There is a voluminous and many-sided, but generally fragmentary, literature on this subject, to which the foregoing discussion is heavily indebted. For an admirably balanced and concise synthesis, with a valuable list of sources, see David Kynaston, King Labour: The British Working Class 1850-1914 (London, 1976). Trygve Tholfsen, Working Class Radicalism in Mid-Victorian England (London, 1976), provides an authoritative analysis of the background to the late-Victorian period. For an illustration of the way in which belated trade unionism lacking roots in Liberalism could develop in close collaboration with ILP Socialism, see J. Reynolds and K. Laybourn, "The Emergence of the Independent Labour Party in Bradford", in: International Review of Social History, XX (1975), pp. 313-46. 
their numbers included Thomas Ashton, the Lancastrian secretary of the MFGB. ${ }^{10}$

At the same time, Socialism began to make a considerable impact on the working-class movement. Trade unionists concentrated on limited reforms, but they were prepared to vote for certain Socialist measures, either as a remote ideal or because they could be represented as practical demands which would benefit the working class. Thus the TUC voted for nationalisation of minerals, metals and the mining industry in 1892, and for collective ownership of the means of production and distribution in 1893, while the MFGB voted for nationalisation of the mines by a substantial majority in $1894 .^{11}$ These muddled and contradictory strands came together at the MFGB conference in January 1897 when a resolution from the Scottish Miners' Federation, the only Socialist-dominated section of the union, called for public ownership of "Land, Minerals, Railways, and instruments of wealth production". This resolution was voted down by a heavy majority in favour of a Yorkshire amendment to act on trade-union rather than Socialist lines. However, another resolution, from Lancashire and Cheshire, confining public ownership to land, mines, mineral royalties and railways, was passed, also by a huge majority. The latter resolution was passed almost as an afterthought with the Yorkshire delegates abstaining, the debate being wholly on the Scottish resolution and the Yorkshire amendment. But the fact that the Lancashire and Cheshire resolution was passed showed that miners had no objection in principle to nationalisation of some industries, provided that it was not represented as a weapon to be used against trade unionism or as a substitute for an immediate programme.

The debate allowed the Yorkshire leaders to demonstrate their hostility to Socialist abstractions. Pickard had declared himself opposed to nationalisation of the mines in 1894 , saying that he thought it would not result in miners being "a penny better off than they are to-day". Now he asked the conference from the presidential chair to decide whether they were, as trade unionists, "idealists or [...] practical men". Delegates wanting to understand the relationship between trade unionism and

${ }^{10}$ Gregory, The Miners, op. cit., pp. 4-5; H. A. Clegg, Alan Fox and A. F. Thompson, A History of British Trade Unions since 1889, I: 1889-1910 (Oxford, 1964), pp. 246-47, 275-76; Raymond Challinor, The Lancashire and Cheshire Miners (Newcastle, 1972), chs 13 and 14. For a description of the Conservative appeal to working-class voters considered historically, see Robert McKenzie and Allan Silver, Angels in Marble (London, 1968), ch. 2.

11 Trades Union Congress, Annual Report, 1892, p. 70; ibid., 1893, pp. 44-48; MFGB, Annual Conference Report, 1894, p. 26. 
Socialism, he said, should read Adam Smith and John Stuart Mill. "I believe in Trade Unionism, and I believe I am as good a Socialist as any man outside who cries down Trades Unionism." Ned Cowey, the Yorkshire president, was, like Pickard, a "practical man". He announced: "I am a Socialist to a certain extent, but I am a 'possibilist'. To me, what is possible, what is practicable." In the future trade unionism might possibly be outmoded, he added, but in the world as then constituted nothing equalled it "for lifting and benefiting the working classes". In the heat of the debate he made plain that his "possibilist" Socialism meant little: "Trades Unionism is Trades Unionism, and Socialism is Socialism. They are two different factions, and it is a hard thing to serve God and Mammon." William Parrott, the third-ranking Yorkshire figure, said in the same debate that state control of the individual should be avoided; his " 50,000 bosses" in the YMA were "quite plenty". ${ }^{12}$

What comes out of this confused rhetoric is belief in the traditional values of Liberalism, fear and misunderstanding of the nature of Socialism, and pride in the achievements of mining trade unionism. Pickard, Cowey, Parrott and Frith were all well into middle age and in the last decade of their lives. They had reason to feel pride in their achievements. It was their generation which had built up permanent mining unions to replace the ephemeral societies of the past. They were effective negotiators who had risked victimisation (Cowey's participation in strikes as a young man had twice cost him his job) and devoted their lives to the achievement of better wages and working conditions. They were the first elected representatives of the miners, on school boards, town and county councils, and, in Pickard's case, in Parliament. ${ }^{13}$ If working and living conditions remained abysmal, as their critics pointed out, progress was undeniable. At the Yorkshire miners' gala in June 1897 John Frith said proudly that the YMA had a balance of $£ 131,011$, despite the severe effects of the prolonged lock-out of 1893. Pickard declared: "You men are working better, healthier, and happier, and your wives are looking better and your children are better dressed and more comely." Cowey said that the

12 MFGB, Annual Conference Report, 1894, p. 15; ibid., 1897, pp. 36-67. See also ibid., 1902, pp. 68-72. The 1897 debate is summarised in R. Page Arnot, A History of the Scottish Miners (London, 1955), pp. 93-96, and Duffy, "The Growth of Trade Unionism", op. cit., pp. 573-78.

13 See John Saville, "Notes on Ideology and the Miners before World War I", in: Bulletin of the Society for the Study of Labour History, No 23 (1971), pp. 25-26; id., "The Ideology of Labourism", in: Knowledge and Belief in Politics: The Problem of Ideology, ed. by Robert Benewick, R. N. Berki and Bikhu Parekh (London, 1973), p. 219. 
membership of the union was 53,000 (out of nearly 72,000 underground workers), and reminisced: "Gentlemen, there has been a great improvement in the class to which I belong during the last fifty years [...]. I as a boy, and all boys at that day, was down in the mine for $12,14,15$, and 16 hours a day [...]. Verily Trades Unionism has wrought a change, even with the capitalists of this country."14

Pickard was a fighter. A little over two months after the Barnsley byelection he declared that a trade union must be aggressive. The man who fought and ran away was not a real trade unionist. ${ }^{15}$ The Yorkshire leaders had fought doughtily for the miners' two principal aims, at variance though they might be with strict Liberal belief in laissez-faire. These were the living wage, as opposed to the earlier sliding scale, which varied with the price of coal, and the legal eight-hour day. ${ }^{16}$ They had organised funds for relief and rescue and hospitalisation. Against their record of devoted leadership, and real if limited achievement, the Socialism of the ILP seemed to most Yorkshire miners to have little to offer. During the 1897 MFGB conference Parrott asserted that miners had achieved more in Britain than in countries where the state played a larger role in the economy. Pickard claimed later that the ILP sought the $£ 130,000$ of the YMA, which was to be "put into a box, and those who had nothing had to put theirs in, and the total was to be shared". But, he added, the YMA funds would not be shared with "the idle scamps of the country and the street-corner loafers". ${ }^{17}$ This passionate belief in a form of independent trade unionism which rigidly excluded Socialist politics was not restricted to the top level of miners' leaders, who had done well out of the system. Edward Rymer, a peripatetic figure who settled in the Barnsley area in 1886 and became a local miners' spokesman, was, like his leaders, an industrial militant and a political moderate. In a letter to a Sheffield paper in October 1897 Rymer rehearsed the achievements of miners' trade unionism over the past forty years and added that

14 Report of Yorkshire Miners' Demonstration, 1897, included with YMA, Minutes and Reports, 1897,pp. 5, 9, 10. For statistics of Yorkshire miners and coal production between 1874 and 1920, see Finlay Gibson, A Compilation of Statistics of the Coal Mining Industry o the United Kingdom (Cardiff, 1922), p. 22. In addition to the 72,000 men who worked underground, there were about 18,000 surface workers attached to the Yorkshire mines in 1897 (ibid.), few of whom would have belonged to the YMA.

15 MFGB, Annual Conference Report, 1898, p. 5.

16 Arnot, The Miners, op. cit., chs III, IV and VIII. Hours spent underground by Yorkshire miners varied over time and place, but in the 1890's probably averaged about $83 / 4$ a day. I am grateful to Dr Neville for assistance on this point. See also B. McCormick and J. E. Williams, "The Miners and the Eight-Hour Day, 1863-1910", in: Economic History Review, Second Series, XII (1959), esp. pp. 226, 228, 238.

${ }_{17}$ MFGB, Annual Conference Report, 1897, pp. 54-55; BC, 23 October 1897. 
the YMA had "accomplished more real good [...] and developed more resources than Socialism could do in a thousand years". ${ }^{18}$

The Lib-Lab leaders of the miners lived at a time when working-class Radicalism could by no means be taken for granted. Cowey and Pickard pointed out that in 1895 and 1900 the electorate had voted Conservative; in both elections Lib-Labs were among the defeated. The first job, Cowey said, was to educate the men in trade-union principles rather than in "speculative business". Then, with Liberal and labour working together, the joint forces would be "the most powerful party for good that the world had ever seen". Pickard similarly found the only present hope in Liberalism: "I say we must work together uittil our temporal salvation is so complete that there may perhaps a day come when the workers of this country can afford to set either party aside and make their own laws. Until that day dawns we must be what we are believed to be, co-workers for Labour". ${ }^{19}$ Again, the view that in existing circumstances a Lib-Lab combination was the only wise policy penetrated to local level, where among some officials the desire to create a labour party in the foreseeable future was discernibly stronger than among the YMA leaders. John Potts, checkweighman at Hemsworth Colliery, chairing a Liberal election meeting during the Barnsley by-election of 1897 , said in the presence of the Liberal candidate that he would favour a labour party at a time when state payment of members of Parliament and of official election expenses would enable working men to be maintained in Parliament. But in the mean time, "the Liberal party was the working man's only hope". Twenty-five years later, when payment of MPs and election expenses had been enacted, Potts was elected Barnsley's first Labour MP. ${ }^{20}$

Behind the often muddily expressed belief of the miners' leaders in adherence to Liberalism it is possible to discern a principled support for supposed Liberal values, pride in trade-union achievements, and the conviction that if the working class would unite with the Liberals they could be triumphant. There was also a rather less principled belief that the Liberal Party was the source of loaves and fishes for well-behaved trade-union leaders. Pickard was elected in $\mathbf{1 8 8 5}$ for Normanton, a seat not far from Barnsley, and in 1897 he remained the only Yorkshire Lib-Lab MP. His

18 S\&RI, 16 October 1897. For Rymer, an interesting character, see Neville, "The Yorkshire Miners", pp. 977-84. See also Neville's introduction and Rymer's reprinted autobiography, The Martyrdom of the Mine (1898), in: History Workshop Journal, No 1 (1976), pp. 220-44, and No 2 (1976), pp. 148-70; cf. ibid., No 3 (1977), pp. 200-02.

19 MFGB, Annual Conference Report, 1897, p. 44; ibid., 1900, p. 3; S\&RI, 26 October 1897; Wakefield Free Press, 30 October.

${ }^{20}$ LM, I October 1897. For Potts, see Dictionary of Labour Biography, II, and Neville, "The Yorkshire Miners", pp. 970-71. 
seat was won without Liberal opposition in return for the support of the YMA for Liberals in the other Yorkshire mining seats: Barnsley, Osgoldcross, Hallamshire, Rotherham, Morley and Holmfirth. ${ }^{21}$ Parrott was briefly Pickard's successor until his own death. Both men held local government office as did.Cowey and Frith. Pickard pertinently and candidly observed in 1890: "When he appeared before his own constituents in the Normanton division he told them he was a Liberal labour representative. As a pure labour member he might not be carried for Normanton." 22 In 1885 eleven Lib-Labs had been returned, six of them miners, and these figures remained fairly constant in subsequent elections. ${ }^{23}$ Only in 1892 had independent labour been able to return candidates. Keir Hardie had lost his seat in 1895, while the other two successful candidates, John Burns and Joseph Havelock Wilson, were effectively Lib-Labs by 1895 . Wilson, hated and despised by the ILP, was one of the strongest supporters of the Liberals in the Barnsley by-election in 1897. The Liberal Party was the obvious choice of the ambitious working man.

The Yorkshire miners' leaders were by no means opposed to workingclass representation in the House of Commons. Indeed, the election of a limited number of trade-union MPs was an essential part of the Lib-Lab creed. Pickard repeatedly spoke in favour of working-class representation, but always in collaboration with the Liberals. Local organisations, supplementary rather than hostile to the Liberals, should be established in major centres of trade-union organisation. "Wherever there were large bodies of workmen, if they desired labour representation they could have it. [...] Let them [...] pass practical resolutions, and carry them out." The miners, he declared on a later occasion, had achieved labour representation for themselves. Other groups of trade unionists should do the same ${ }^{24}$ By the end of the century the challenge of the ILP and the Labour Representation Committee required more vigorous and urgent action. Pickard, declaring the need for at least seventy MPs to represent the MFGB, called for the creation of a miners' "labour fund scheme" in a series of statements and speeches. But the scheme, finally adopted late in 1902, was specifically intended to ward off the proponents of independent

21 Gregory, The Miners, pp. 106-07.

${ }^{22}$ TUC, Annual Report, 1890, p. 37.

${ }^{23}$ Cole, British Working Class Politics, op. cit., pp. 264-71.

24 TUC, Annual Report, 1890, p. 37; MFGB, Annual Report, 1898-99, p. 25. For a vivid recollection of Cowey and his support for labour representation, see Frederick Rogers, Labour, Life and Literature (London, 1913; reprinted Brighton 1973, ed. by David Rubinstein), p. 219. Cowey's principal contribution was to move repeated resolutions at the TUC during the 1890's in favour of payment of MPs and official election expenses. 
labour action. With the Liberals in mind its rules declared that it was "not established for the purpose of wrecking any political party". ${ }^{25}$

Pickard had established by the 1890's a domination over the MFGB unparalleled until that date by any other trade-union leader and strongly foreshadowing the role of Ernest Bevin on a rather wider stage forty years later. Beatrice Webb, who attended the MFGB conference in 1896, described him in these terms:

$\mathrm{He}$ is a disagreeable person - suspicious, irascible, autocratic - his best characteristic being a pigheaded persistency in sticking to certain principles such as wages ruling prices and a legal day. [. . . It is almost impossible to understand why Pickard is allowed to rule with such a high hand, unless it is because he is a bully, holds himself aloof, and knows his own mind. To look at he is an ugly, surly brute with small suspicious eyes, an unwieldy corporation, red face and unpleasant manner - a cross between a bull-dog and a pig. [...] Pickard rules because he is the only really strong personality, the only man with a sufficiently big ambition. ${ }^{26}$

The hold of this strong personality was enhanced by the nature of mining communities. Over the bitter decades miners had learned that the supreme virtue was solidarity. Experience had taught them that in industrial battles only total unity over a prolonged period could hope to avert defeat. This solidarity spilled over from the industrial to the political sphere. Montagu Blatchford, brother of the editor of the Socialist Clarion, Robert Blatchford, wrote in a notably dispassionate article during the Barnsley election campaign that most mining villages were very dull, with no meeting place or amusement apart from the public house. It was accordingly not surprising that miners had little social and intellectual refinement. They were ignorant and narrow-minded, but loyal. "These careless, thoughtless, hard-working, hard-living fellows have only one political beliee - and that is a belief in Ben Pickard." As a result the union had achieved enormous influence over their lives. A Times correspondent pointed out: "It is difficult to convey to outsiders an adequate notion of the power wielded by the Miners' Federation. It is, to all intents and purposes, a Radical organization in Parliamentary elections in South Yorkshire." Both Blatchford and the Times correspondent commented on the role of the deputy foremen, ardent Liberals constantly in communication with

25 MFGB, Annual Reports and Annual Conference Reports, 1898-1902. See summaries in Arnot, The Miners, pp. 352-62; Gregory, The Miners, pp. 19-20, 23-25; Duffy, "The Growth of Trade Unionism", pp. 627-36, 770-73. Pickard did occasionally criticise the Liberals or strike an independent pose, but he maintained his Lib-Lab status to the end. 26 Beatrice Webb's diary (typescript transcription), 15 and 17 January 1896, British Library of Political and Economic Science. 
Pickard. The deputies attended election meetings to ascertain which men supported resolutions in favour of the ILP. Those who did so feared, rightly or wrongly, to find themselves in worse jobs with lower pay. ${ }^{27}$

Accusations of tyranny were directed against Pickard by Socialist and Conservative alike. Yet such accusations at least in part missed the point. For all his bullying and determination to get his way, brought out at the Barnsley by-election as never before, Pickard remained leader because he provided the rank and file with industrial and political leadership they were prepared to accept. Cowey pointed out at a Liberal victory rally after the election that most of the miners had been educated from boyhood in "sturdy Radicalism". As the Conservative Barnsley Independent commented, the problem for the Tories lay in the miners, not in Pickard. "When the miners are converted it will not matter much whether $\mathrm{Mr}$. Pickard is converted or not." Cowey asserted that a thousand Coweys or Pickards could not have weaned the miners from their Radical allegiance, ${ }^{28}$ and while this statement is open to doubt, in that an alliance between the ILP and the miners' leaders would probably have won over thousands of miners' votes, it was certainly true that the YMA leadership satisfied the existing political loyalty of most members. Identity of view between leader and follower was cemented by religious affiliation. Nonconformity made a strong appeal to the Yorkshire miners, and Methodism in particular provided religious, emotional and recreational outlets. Mining trade unionism was closely associated with chapel life, and among the Yorkshire leaders Pickard was a Wesleyan, and Parrott and Cowey were Primitive Methodists. All three had been lay preachers. ${ }^{29}$

After Pickard's death those who had quarrelled with him over political matters, including Socialists like Robert Smillie of the Scottish miners and Herbert Smith of his own YMA, spoke in glowing terms of his qualities as a leader. Somewhat ironically, at a meeting in London in 1904 tributes paid to Pickard were accepted on behalf of the YMA by James Walsh, an ILP'er

27 Clarion, 30 October 1897; Times, 21 October; also Pete Curran in I.L.P. News, November.

28 BI, 6 November 1897.

29 Robert Wearmouth, Methodism and the Struggle of the Working Classes 18501900 (Leicester, 1954), pp. 173-74, 194-96; id., The Social and Political Influence of Methodism in the Twentieth Century (London, 1957), pp. 144-50; Saville, "The Ideology of Labourism", loc. cit., p. 219; Neville, "The Yorkshire Miners", pp. 447-48, 829-30, and biographical appendix. For an excellent study whose implications reach far beyond the local community, see Robert Moore, Pit-men, Preachers and Politics: The effects of Methodism in a Durham mining community (London, 1974). Robert Colls, The Collier's Rant (London, 1977), is another recent historical study of the miners of the North-East, stressing the importance of Methodism and drawing heavily on verse, song and fiction. 
and a strong critic of Pickard. Referring also to the recent death of Cowey, Walsh said that under the influence of the two men trade-union membership among Yorkshire miners had grown from 7,000 to 66,000. "We young men", Walsh commented, in words which were more than a conventional eulogy, "who have grown up under their tuition, have had to differ from them with regard to methods of organisation and so on; but, nevertheless, we always agreed to differ, and we admired them because of their moral courage and high integrity in the industrial world, and their great influence in discussing grievances before employers." 30 Such leaders were unlikely to be deserted by the membership in a crucially important by-election.

During the Barnsley campaign the miners' leaders and the unashamedly biased Liberal press constantly accused the ILP of collaborating with the Conservatives, accepting Conservative money and deliberately setting out to ruin the YMA. These allegations were untrue. The ILP had no open or secret alliance with the Conservatives, was not financed by them, nor was it hostile to trade unions. Several of the ILP leaders had an excellent record of trade-union activity, and one of the party's principal aims was to work with the unions and convert them to Socialism. But on a more subtle level the accusations hurled at the ILP were not without foundation. If the party was to make electoral progress it could do so only by superseding the Liberal Party, particularly by appealing to voters in strongly Liberal areas. To that extent the Liberals were the principal enemy, "partywrecking" the aim, and implicit or open alliance with the Conservatives the inevitable result.

ILP candidates in the General Election of 1895 outraged Lib-Lab sentiment and probably cost the Liberals a number of seats. Again, Keir Hardie's candidacy in a Bradford East by-election in November 1896 probably enabled the Conservatives to retain the seat and led to bitter strife between the ILP and the Liberals. In Barnsley in the same month locally important circumstances persuaded the trades council, which was to support the ILP in the by-election of 1897 , to assist a Conservative blacksmith in depriving the miners' leader William Parrott of his seat on the town council. In a by-election at Sheffield Brightside in August 1897, ILP opposition to the Lib-Lab Fred Maddison led to implicit support for the Conservative, a duke's nephew, in a straight fight. (Maddison won a narrow victory and responded by attacking the ILP during the Barnsley by-election with notable venom.) These ILP-Liberal clashes gave the Liberals a weapon which was well used in the Barnsley contest in the autumn of 1897. A typical

${ }^{30}$ MFGB, Report of Delegates' Meeting, 4 February 1904, pp. 5-6; Robert Smillie, My Life for Labour (London, 1924), pp. 68-69; Jack Lawson, The Man in the Cap (London. 1941), p. 85. See the tributes to Pickard in Arnot, The Miners, pp. 53, 103, 207, 302, 322. 
instance occurred at an election meeting when a bystander shouted at the ILP candidate: "Whar's thi money co' fra'!", and another cried: "Tha'll nobbut let Toory goo in." ${ }^{31}$ Soon afterwards ILP-Liberal hostility reached a bitter climax. Personal and political factors at a by-election in York in January 1898 caused the local ILP branch to give open backing to the Conservative candidate, who won the seat by eleven votes out of over $11,000 .^{32}$

There was also ammunition for the charge that the ILP engaged in union wrecking. Keir Hardie was widely quoted as having declared in 1896 in a speech at Rothwell, which lay within Ben Pickard's Normanton constituency, that trade unionism was "played out" and a "worn-out system". Tom Mann also became notorious for calling the majority of the TUC, meeting at Birmingham in September 1897, "a dead, dull, matter-of-fact, fat-headed show". ${ }^{33}$ Mann stood by these words, but Hardie claimed that he had been seriously misquoted. Nonetheless, his alleged remarks had an important element of accuracy. He had been a committed trade unionist, and Mann and other prominent ILP members remained so, but they certainly felt that the type of leadership exemplified by Pickard and Cowey was "played out". They also felt, as Hardie later explained in clarifying his Rothwell speech, that "trades unionism [. . . did not go far enough". The working class required a Socialist party to lead their cause in the political field as unions did industrially. ${ }^{34}$ Adherents of the ILP among the Yorkshire miners wanted to break the hold of the existing leadership and develop a kind of trade unionism which would have strong links with Socialist politics.

The miners of Rothwell, under the leadership of the future Labour MP and government minister Willie Lunn, were the principal source of ILP strength among the Yorkshire miners. ILP members like Lunn and James Walsh, while still in a small minority, were beginning to enjoy an increased following, which might make them dangerous rivals to Pickard and his colleagues. ILP activity within his constituency must have been parti-

31 Pall Mall Gazette, 27 September 1897.

32 Figures for general and by-elections may be found in F. H. McCalmont, Parliamentary Poll Book of All Elections, 1832-1918, 8th ed. (Brighton, 1971). For the General Election of 1895, see TUC, Annual Report, 1895, pp. 27-31, and ILP, Annual Conference Report, 1896, pp. 4-5, 14-15; for the Bradford election, Times, 5 and 6 November 1896; for the Barnsley council election, BC and BI, 31 October and 7 November 1896; for Brightside, LL, 14 August 1897, ILP, NAC minutes, 9 October 1897, and Labour Chronicle, September; for York, ILP, Annual Conference Report, 1898, pp. 9-10.

33 Wakefield Free Press, 4 July 1896; LM, 10 September 1897.

34 MFGB, Annual Conference Report, 1897, pp. 43, 47, 51-52; Derbyshire Times, 11 September 1897; BC, 2 October. 
cularly annoying to Pickard. At the time of the Barnsley by-election Walsh had just led, and Lunn was deeply involved in, long and bitter strikes, disliked by the YMA leadership, at the South Kirkby and Middleton Collieries. Both men gave active support to the ILP in the election. ${ }^{35}$ This new generation of Socialists, even if it had been far stronger than it was, could not have taken over the YMA during the older leaders' lifetime without a major split in the union. Such a consideration was the only justification for the otherwise unscrupulous campaign of the YMA leaders and for the insistence of Liberal politicians and press that, in the typical words of the Leeds Mercury, "discord and disunion amongst the miners were the aim and object" of the ILP. ${ }^{36}$ A second-rank YMA leader, James Murray, who had been an outspoken opponent of Pickard and a member of the ILP, supported the Liberals in the Barnsley campaign, saying he would fight "any one [who] came to strike at a society which he had helped to build up, and which he had suffered and fought for". 37

The ILP, in short, was a potentially dangerous enemy of what by 1897 had become traditional trade-union leadership and traditional Lib-Lab Radicalism. It was potentially a "wrecker" of both the Liberal Party and the YMA. The miners' leaders had long believed in gradualism, moderation and class collaboration in the political field, no matter how vigorously they fought industrial battles, often defensive, over wages and hours. The Socialist solutions of the ILP ran counter to all their experience and philosophy. Unaccustomed to opposition from their left and aware of the challenge they now faced, Pickard and the other leaders reacted with bitter hostility to the Socialist forces invading the heart of their camp.

The Barnsley by-election was occasioned by the death on 11 September 1897 of the fourth Marquess of Northampton. His eldest surviving son, Earl Compton, had been the Liberal member for the division. Formalities over Compton's accession to the title delayed the election until 28 October. As the Liberals, first in the field, adopted their candidate on 16 September, the campaign lasted for six weeks. This produced a marked battle-weariness among candidates, helpers and voters, but, because of the ILP intervention, gave unusual prominence to Barnsley and the election. The Liberal Barnsley Chronicle observed quaintly: "Barnsley has never before

35 Yorkshire Post (hereafter YP), 19 August 1897; S\&RI, 27 and 28 September; BC, 23 October. For Lunn, see Dictionary of Labour Biography, II, and Neville, "The Yorkshire Miners", pp. 955-57.

36 LM, 30 October 1897.

37 S\&RI, 30 September 1897. 
bulked so largely in the public eye [...]. It has become quite a town of importance."38

The constituency, which had been created in 1885 , was solidly Liberal, although the Conservative share of the poll in the five elections before 1897 had risen from 28.9 to 40.6 per cent ${ }^{39}$ Eleven Liberals sought nomination at the by-election, and the successful contender, Joseph Walton (1849-1923), was chosen against strong opposition. Among his rivals were three former MPs, W. P. Byles, W. S. Caine and G. W. E. Russell, all of whom had achieved some degree of prominence, and a number of previously unsuccessful Liberal candidates, including C. P. Trevelyan, the future Liberal and Labour MP and cabinet minister, and A. E. Fletcher, a Radical journalist with ILP sympathies who had previously edited the Daily Chronicle and was now editor of the weekly New Age. ${ }^{40} \mathrm{~W}$ alton was a colliery owner and coal dealer in County Durham who had travelled extensively and was an ardent advocate of Empire. He had first stood for Parliament in 1895 when he had been very narrowly defeated at Doncaster. After his successful campaign at Barnsley in 1897, Walton continued to sit for the constituency until 1922. He was created a baronet in 1910. The ILP alleged that Walton achieved nomination by lavish promises of financial support for the Liberal Party in the constituency. According to Keir Hardie, Walton offered to pay all his election expenses and contribute $£ 500$ a year to the Liberal organisation; as he was the "highest bidder [. . .], the seat was knocked down to him."41

Despite his occupation Walton seems to have had YMA support from the beginning, for his nomination, according to the Leeds Mercury, was moved at the selection meeting of the Barnsley Liberal executive committee by John Frith, financial secretary of the YMA. ${ }^{42}$ At the subsequent formal adoption ceremony Walton's proposer was the Rev. George Hadfield, who, as Congregational minister of Wombwell, was a leading local figure and a major architect of the town's reputation as a Radical stronghold. The seconder was William Parrott, the YMA agent. It had been asked, Parrott commented, "why a Labour candidate had not been brought out, and why a gentleman of means, and a colliery proprietor, was nominated". Why was he not standing himself? The answer was partly that Walton was "a man equal to any working man candidate". But also,

38 BC, 30 October 1897.

39 British Parliamentary Election Results 1885-1918, ed. by F. W. S. Craig (London, 1974), p. 432.

40 LM and Times, 16 September 1897.

41 YP, 28 October 1897; LL, 6 November.

42 LM, 18 September 1897. 
Parrott said, "No working man with ordinary wages could afford to contest a Division like that. It was a great tax upon some of them to contest a ward even in a borough." 43

The Conservative candidate, whose occupation was stated as "gentleman", was James Blyth (1869-1925). Blyth, a Londoner, was a captain in the 4th battalion of the Oxfordshire Light Infantry, a militia regiment. He was new to political life and this election was to be his only attempt to enter Parliament. It was asserted that the Conservatives had difficulty in obtaining a candidate, as well they might, for not only was Barnsley a Liberal stronghold, but also the by-election tide was flowing against the Conservative government. Blyth's name was suggested to Barnsley Conservatives by his friend and Etonian schoolfellow Lord Milton, member for Wakefield, heir to Earl Fitzwilliam and an influential figure in Conservative politics in South Yorkshire. ${ }^{44}$

The ILP took careful soundings before determining to contest Barnsley. Its Parliamentary Committee held a meeting in Leeds on 15 September, shortly after Northampton's death, and decided to hold a series of meetings in the constituency to test feeling about an ILP candidate. In the mean time Pete Curran, S. G. Hobson, Joe Grady, Joe Burgess, Bruce Glasier and Ben Riley were asked to consider standing, and other leading ILP figures to attend the division as speakers. ${ }^{45}$ Two decisive events persuaded the ILP to put up a candidate. The first was that at meetings held at Barnsley, Wombwell and Hemsworth (with 800 miners present) audiences enthusiastically supported the plan for a candidate. The second was a meeting of the Barnsley and District Trades and Labour Council, held on 22 September, which voted unanimously to support an ILP candidate. This latter move was not, however, as hopeful an augury as it appeared. Miners were not represented on the trades council, although several miners' lodges sent delegates by invitation to this meeting. Furthermore, several delegates left before the vote was taken and; although about twenty societies had been represented, only about a dozen delegates remained to give unanimous support to the motion in favour of the ILP. The vote was subsequently challenged, partly on the grounds that it was politically wrong, and partly because support for a candidate nominated by a political party was in apparent breach of the council's rules. Nonetheless, the earlier action was confirmed by ten votes to three. The trades council included no union branches outside Barnsley itself, and without the miners it

43 BC, 25 September 1897.

44 YP, 22 September 1897; Daily News, 22 and 23 September; LL, 2 October.

45 ILP, Parliamentary Committee minutes, 15 September 1897, British Library of Political and Economic Science. 
represented the organised working class of only a small section of the constituency. ${ }^{46}$ The ILP offered to put up a local candidate if the trades council preferred, an offer which was not taken up. The Barnsley ILP branch wished to run Tom Mann, but Mann had promised himself as candidate to Crewe, where a by-election seems to have been expected, although none in fact took place. There may have been some truth to Ben Pickard's charge that had the Barnsley seat been winnable by the ILP, Mann and Keir Hardie would not have held back. ${ }^{47}$

The candidate finally settled on was a colourful character, Pete Curran (1860-1910). ${ }^{48}$ Curran's drink-induced early death has sometimes caused him to be overlooked among the early leaders of the labour movement. Glasgow Irish by birth, he was at under forty a hardened veteran of the trade-union and Socialist movements. In 1889, the year of its foundation, he had been appointed a regional organiser of the National Union of Gasworkers and General Labourers and, shortly afterwards, general organiser of the union. In 1897, still holding this post, he was recognised as a principal spokesman of the "new" trade unionism. As the Manchester Guardian pompously commented, he was "intimately acquainted with the needs and aspirations of what is called unskilled labour". ${ }^{49} \mathrm{He}$ had attended the Trades Union Congress annually since 1891, and, although not a member of its executive, the Parliamentary Committee, he was a popular and respected figure and a principal leader of the TUC Socialist faction. He had moved at the TUC held at Birmingham in September 1897 a resolution on behalf of the Parliamentary Committee in support of the locked-out engineers, and had been supported by Ben Pickard, who scorned him as a "Tory sop" a few weeks later. Curran was a founder member of the ILP and, by 1897, the longest-serving member of its executive, the National Administrative Council. He had stood for Parliament at Barrow in 1895, but had finished a bad third with only 414 votes. The press acknowledged his ability as a candidate, the Barnsley Chronicle calling him "genial, fluent, and eloquent", while from the Conservative side of the political divide the Yorkshire Post patronisingly pronounced him "a favourable specimen of the Labour agitator". ${ }^{50}$ After Curran's death his colleague and friend Will Thorne, secretary of the gasworkers' union, wrote a glowing tribute, which included this passage: "He had many

$46 \mathrm{BC}$ and BI, 25 September and 23 October 1897.

47 Evening Standard, 23 September 1897; YP, 20 October; BC, 23 October.

48 I am indebted to Barbara Nield for showing me an advance copy of her account of Curran from the Dictionary of Labour Biography, IV (1977).

49 Manchester Guardian, 27 September 1897.

50 BC, 23 October 1897; YP, 25 September. 
qualities, but he excelled as a public speaker - eloquent, witty, sometimes sarcastic, and capable of delivering sledgehammer attacks of logic. He was always bright and cheerful". ${ }^{51}$

The gasworkers' union had a surprisingly large number of members in the constituency. Figures published in the press and union records alike suggest a membership of between 1,200 and 1,300 at the time of the by-election. This was a sizeable proportion of a national membership which had fallen to 25,532 in 1895 before recovering to 40,042 in 1897 . Most members were employed as labourers in various industries, including surface workers and pit enginemen in mines around Barnsley. There was a hint of inter-union rivalry with the YMA, though the miners' leaders showed little interest in recruiting surface workers. ${ }^{52}$ Even had the gasworkers voted in a block for Curran, however, the number of members was less significant than it appeared, for at a time when stringent registration qualifications and other barriers withheld votes from many men, labourers of the kind who belonged to the gasworkers' union were often disenfranchised. ${ }^{53}$

Each side had its plan of campaign. The Liberals stressed their close links with labour and put forward Walton as a kind of Lib-Lab candidate. Not only Pickard, Cowey, Parrott and Frith among the Yorkshire miners' leaders, but many other prominent Lib-Labs also spoke on his behalf, including Havelock Wilson and Leslie Johnson of the seamen, Edward Harford of the railwaymen, Fred Maddison, the recently elected member for Sheffield, and Joseph Toyn and W. E. Harvey, leaders respectively of the Cleveland and Derbyshire miners. It was claimed that the "Three Hundred", as the Barnsley Liberal organisation was called, was overwhelmingly composed of working men, Walton himself asserting that nearly three-quarters, or alternatively 280 out of 324 , were "men who

51 Will Thorne, My Life's Battles (London [1925]), p. 94.

52 Times and Sheffield Daily Telegraph, 24 September 1897; YP, 28 September; BC, 16 and 23 October; Daily News, 30 October; H. A. Clegg, General Union in a Changing Society (Oxford, 1964), pp. 32, 34; Report by the Chief Labour Correspondent of the Board of Trade on Trade Unions in 1899 [Cd 422], pp. 122-23; quarterly balance sheets of National Union of Gasworkers and General Labourers, quarters ending 30 September and 31 December 1897, kindly supplied by Andrew Dismore of the General and Municipal Workers' Union.

53 Sheffield Daily Telegraph, 20 October 1897; S\&RI, 30 October; Clegg, Fox and Thompson, A History of British Trade Unions, op. cit., I, pp. 269-71; Gregory, The Miners, pp. 9, 190; Neal Blewett, "The Franchise in the United Kingdom 1885-1918", in: Past \& Present, No 32 (1965), pp. 27-56. See also H. C. G. Matthew, R. I. McKibbin and J. A. Kay, "The Franchise Factor in the Rise of the Labour Party", in: English Historical Review, XCI (1976), pp. 723-52. 
earned their daily bread by manual labour". (For the ILP, James Walsh said that this claim was grossly inflated. $)^{54}$ Walton's campaign centred round the legal eight-hour day for miners, the legislative demand which was at the heart of the miners' programme and which was rightly called "the alpha and omega of the contest". ${ }^{55}$ Walton did not support the legal eight-hour day for all workers, as Curran did, but this lost him no support among the miners' leaders; Pickard termed him as or more Radical than he was himself, and said that Walton put "Labour first, and Liberal after". Walton pointed out that he was the grandson of a lead miner who had had 14 children to raise, and declared: "I am, and always have been, in favour of trades unionism. If I had the honour of earning my daily bread by the use of my hands I should be one of the strongest trades unionists in the country." 56

Walton's programme included such Radical measures as reform of the land laws, a fairer electoral registration system, shorter Parliaments, abolition of plural voting, restriction of the power of the House of Lords and the Church of England, home rule for all parts of the United Kingdom, payment of members of Parliament and official election expenses, and other political reforms. He called also for such social measures as the appointment of working men to factory and mines inspectorships, stateaided old-age pensions, improvements in poor-law administration and "reforms calculated to promote a Higher Social Condition of English life". ${ }^{57} \mathrm{He}$ was attacked by the ILP for not accepting the whole of the miners' national programme, which since January 1897 had included nationalisation of the mines, land and railways. Failure to advocate nationalisation did not distress the YMA leaders, as seen above, but at one election meeting Walton did express under pressure his willingness to bring in a bill to nationalise mines and railways. Asked at about the same time to say whether he was a Socialist or an Individualist, he replied: "I am a Socialist in some questions and an Individualist in others, according as I think it will promote the benefit of the whole community." 58

Although Walton was little more than the prisoner of the YMA leaders during the election campaign, it is fair to assume that his position was determined by considerations other than short-term expediency. He belonged to that wing of the Liberal Party which, by the late 1890 's, realised

54 S\&RI, 19, 26 and 28 October 1897; BI, 25 September.

55 Daily News, 20 October 1897.

56 BC, 25 September and 2 October 1897; BI, 9 October; LM, 26 October.

57 LM, 21 September 1897; Wakefield Free Press, 2 October.

$58 \mathrm{BC}$ and BI, 2 October 1897; S\&RI, 28 September and 1 October. 
that both principle and expediency dictated close co-operation with the more amenable section of the labour movement. The power of labour was acknowledged and praised by many Radical politicians and journals, and support was given to labour struggles, including the engineers' lock-out then taking place. C. P. Scott's Manchester Guardian wrote typically: "Liberalism can be strong only when it is true to its ideal as the champion of all that is best and sanest in the labour movement."59 A rather more revealing statement was made by Courtney Kenny, who had been the first member for Barnsley and had retained the seat until his resignation to take up a readership in law at Cambridge. Kenny thought, like Walton, that the workers' cause would be all the stronger for being supported in the House of Commons by an employer, and added: "It was in the alliance of classes, in the union of capital and labour, [...] in the unanimous pursuit of the great principle of progress by employer and employed alike, that they would find the real foundation of the unfailing victory of their principles."60

The Conservatives could not hope to match the Liberal strategy, for they were outgunned in both quantity and quality. Walton was praised even in their press as a resilient, skilful and indefatigable campaigner, while Blyth, the youngest of the candidates, was dismissed by his opponents as a pleasant but inconsequential young man. His strong card was the recent passage by the Conservative government of the Workmen's Compensation Act, a measure to provide benefits in cases of injury or death considerably in advance of that which the last Liberal government had unsuccessfully attempted to pass in 1893-94. He supported also old-age pensions and measures to enable working men to purchase their homes. ${ }^{61}$ However, the Workmen's Compensation Act was a double-edged sword. The backbone of Barnsley Conservatism consisted of local mine-owners, who felt themselves badly treated by the Act, which they feared would greatly increase their costs. As a result, apart from the divisional Conservative chairman, Howard Allport, who was ill during much of the campaign, only two colliery owners spoke on Blyth's behalf. Both made clear that they did so despite the sense of grievance against the government under which they

\footnotetext{
59 Manchester Guardian, 30 October 1897. The Daily Chronicle and the Leeds Mercury wrote on the same day in similar terms, affirming their belief in Liberal-Labour alliance. For an analysis of the intellectual rationale of the "New Liberalism" of the period, see P. F. Clarke, "The Progressive Movement in England", in: Transactions of the Royal Historical Society, Fifth Series, XXIV (1974), pp. 159-81.

60 BC, 16 October 1897.

61 Daily Chronicle, 25 September 1897; Wakefield and West Riding Herald, 2 October; BI, 6 November.
} 
laboured, while Allport tried to straddle the issue. Lord Londonderry, the powerful mine-owner and Conservative leader of the North-East, did not help Blyth by pronouncing in strong terms against the Act during the campaign, though the Blyth camp tried to make the most of the courageous action of a government prepared to defy so important a supporter. Day after day the more candid Conservative papers wrote about the apathy among local Conservatives, partly due to divisions over the workmen's compensation question. ${ }^{62}$

What told even more powerfully against Blyth was the fact that he opposed the legal eight-hour day for miners, arguing that while he was not against eight hours on principle, it was not demanded by all British miners ${ }^{63}$ and should be won by trade-union action rather than by legislation. This was a bold position to take and one not shared by all Conservatives. Blyth's friend and patron Lord Milton was one of the Conservatives who had voted for a miners' eight-hour bill in the House of Commons in May 1897. In a mining constituency like Barnsley, in a campain which revolved around the eight-hour question, Blyth's stand was fatal to his chances. Even Conservative miners, it was said, refused him their support because of his opposition to their wishes on the issue. ${ }^{64}$

Curran and his supporters had their plan of campaign ready made. This was to portray him as the candidate of trade unionists and Walton as a grasping capitalist. Curran's election address called for the nationalisation of land, mines, minerals and railways, the official policy of the MFGB, and for municipalisation of gas, water, trams and other services, making clear that these should be seen as "stages leading to the development of Socialism". He promised to support a virtually universal eight-hour day, taxation of unearned rather than earned income, the right to work, local control of the drink trade, school meals for needy children and Irish Home Rule. In general, his campaign was that of the trade unionist rather than the Socialist. "Why", he asked, "should the coming forward of a trades unionist like himself, to contest a working-class constituency, be considered a blow at any trade society?" Working men should vote for another working man, a trade unionist who understood the problems of other trade

62 Pall Mall Gazette, 4, 18, 25 and 28 October 1897; Sheffield Daily Telegraph, 23 and 26-30 October; YP, 5, 16, 19, 20, 26 and 27 October; LM, 16 October; Annual Register, 1897, pp. [201-02].

${ }^{63}$ Hewers in Durham and Northumberland worked a seven-hour or shorter day and opposed the eight-hour demands of their MFGB colleagues. There was also some opposition to the eight-hour day among miners in Lancashire and South Wales. Gregory, The Miners, pp. 17-18.

64 Parliamentary Debates, Fourth Series, XLVIII, c. 1581 (5 May 1897); YP, I October 1897; BI, 16 October; Pall Mall Gazette, 28 October. 
unionists, not for candidates put forward by the employers' parties. ${ }^{\text {ib }}$ But in a speech delivered during the Barnsley campaign to the locked-out engineers of Leeds he declaed that industrial action alone was inadequate. The policy of striking was "barbarous" and caused severe distress to workers' families. Workers must join together for political purposes as well as in trade unions in order to defeat "class privilege and monopoly". ${ }^{66}$

It was not difficult to characterise Walton as a capitalist. He was, in fact, an astonishing choice as the joint candidate of Barnsley liberals and the YMA leadership. Only four years previously there had been a prolonged and bitterly fought lock-out in the MFGB district. At Featherstone, near Pontefract and only about a dozen miles from Barnsley, troops fired on a crowd. Two men were killed and a number of others injured. A Times correspondent commented in 1897 that the memory of the lock-out would take years to obliterate: "To many families it meant terrible suffering; to the whole countryside it meant a state of bankruptcy, the effects of which have not passed away." 67 During the lock-out Walton, merchant as well as colliery owner, had profited from the lack of coal in Yorkshire to ship in supplies from Durham. According to the Conservative Sheffield Daily Telegraph he had denied doing this in his Doncaster campaign in $1895 .{ }^{68}$ Now, however, faced with the direct query whether he had sent coal to South Yorkshire in 1893, he replied: "Yes, I did, just in the same way that you Barnsley miners and the coal sellers in Yorkshire sent coals to Durham during the Durham strike." In the Durham strike of 1892, however, Walton himself had apparently purchased coal in the Barnsley district to sell in Durham. ${ }^{69}$ Not unreasonably the Sheffield Daily Telegraph satirically attributed these words to Ben Pickard in its comment on the election result:

Look here, you fellows. You know what I told you the other day about the

$65 \mathrm{BC}, 16$ October 1897. There are copies of Curran's election address and his first speech as adopted candidate (24 September) in the Barnsley Central Library and the National Museum of Labour History, London. The election address is also reprinted in Barbara Nield's account referred to in note 48 . The address and the speech (the cover of the latter is reproduced by courtesy of the National Museum of Labour History) form a valuable document, since Curran was inadequately reported in much of the press.

66 LM and YP, 18 October 1897.

67 Times, 21 October 1897. For detailed accounts of the 1893 lock-out in the Yorkshire coalfield, see Neville, "The Yorkshire Miners", ch. IV, and id., "The Yorkshire Miners and the 1893 Lockout: The Featherstone 'Massacre",, in: International Review of Social History, XXI (1976), pp. 337-57. Violence extended far beyond Featherstone (and indeed beyond Yorkshire), and affected both Barnsley and Wombwell.

68 Sheffield Daily Telegraph, 6, 26 and 28 October 1897.

69 BC, 25 September and 2 October 1897; YP, 28 September and 26 October; LL, 16 October. 


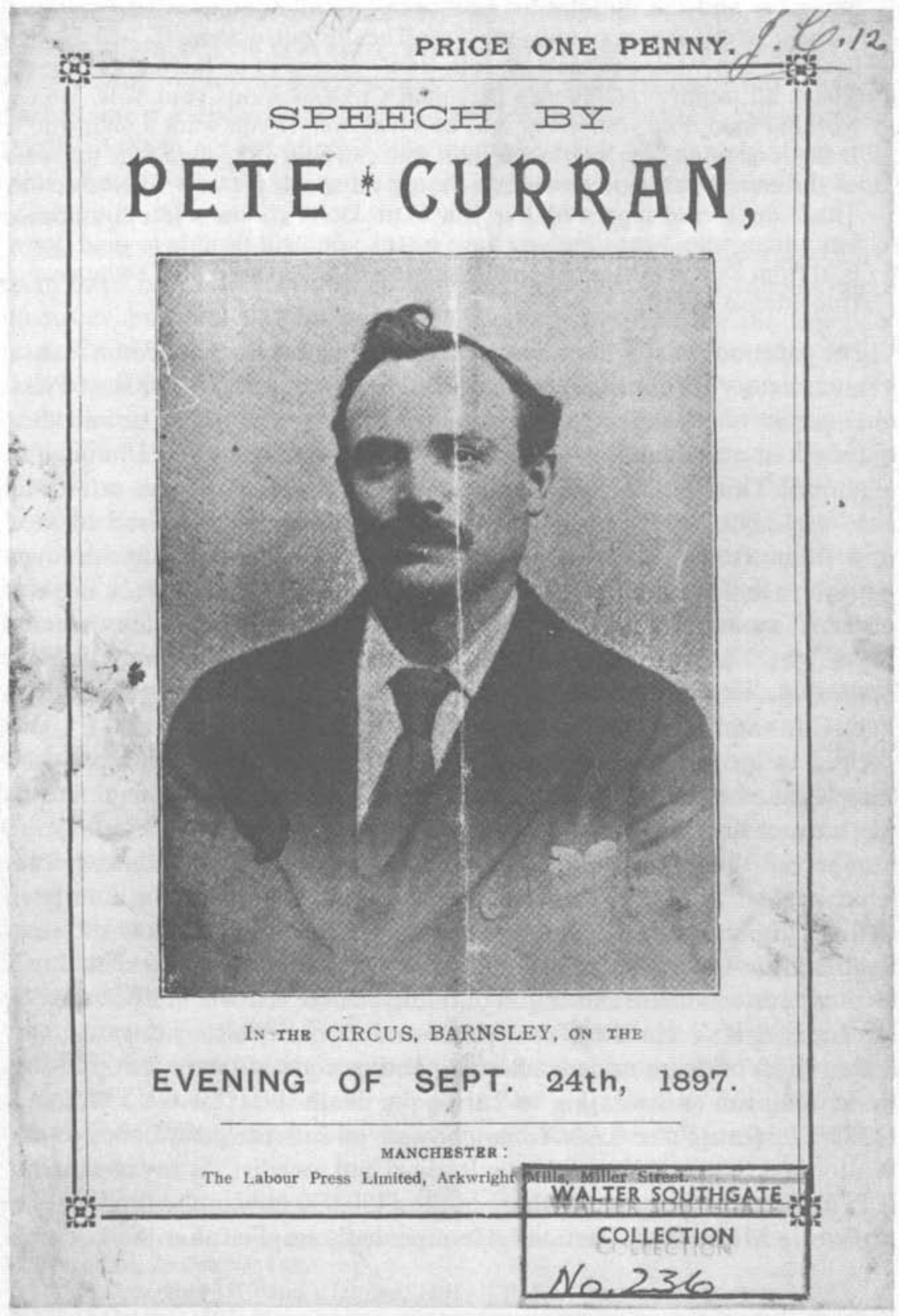


employer and the middleman being the natural enemies of the working classes? Well, that was only my fun. They're not octopuses, and bloodsuckers, and vampires, and tyrants, and oppressors of the working man. That's all tommy-rot. There's that man CURRAN wants your vote. He's a working man, like yourselves; but he's no good. If you want a man who'll really look after your in terests, a man who can be trusted to put the interests of the miner first and foremost, choose an employer and a middleman. That's the sort of representative you want. Don't choose a trades unionist, but a man who, next time you have a strike on, will be able to send down coal from Durham so as to help the masters to defeat you. That's where your true interest lies. ${ }^{70}$

The election was in fact dominated by Pickard, and its result was a greater victory for him than for Walton. The extent and passion of Pickard's commitment were a striking feature of the campaign, and he said later that he had never fought so hard in his own elections as he had done for Walton. ${ }^{71}$ This was not only because his Normanton seat was safe from challenge, but because he was unaccustomed and unprepared to face opposition from a section of the labour movement within his own Yorkshire fief. As the Yorkshire Post aptly commented: "Mr. PICKaRD is a monarch among the miners of South Yorkshire, and very jealous is he of his crown [. . . . Mr. PICKARD paces his castle walls like the legendary giant, muttering, ' $\mathrm{Fe}$, fo, fi, fum; I smell the blood of a Labour Man', and Mr. Pete Curran had better get his bicycle oiled for flight."72

Even in an age accustomed to vigorous cut and thrust in its political campaigns, the fury of Pickard's onslaught against fellow trade unionists was extraordinary. Soon after the campaign began he sent a letter to a number of Yorkshire papers which set the tone for what followed. The letter began: "Sir, - If there were nothing else at stake than notoriety, self-seeking and self-aggrandisement, the varied characters now showing their faces to the workers in the Barnsley Division would appear to those most interested a mere exhibition of fatuity. There is much more at stake". He accused Keir Hardie, Tom Mann and James Walsh, his antagonist within the Yorkshire miners (though naming none of them), of opposing trade unionism and wanting to "strike the death blow" at the YMA and MFGB "because the knee is not bowed to Independent Labourism". Walton was "as good if not a better Radical and socialist" as any man in the ILP, and he did not wish "a share in the $£ 130,000$ now in the funds of the Yorkshire Miners' Association". He repeatedly implied that the ILP was

72 YP, 27 September 1897. 
acting in league with and financed by the Conservatives, and added: "The honour of our miners is at stake, and [ . . ] I [ . . ] personally consider any man seeking to prevent a real supporter of the eight hours by law going to Parliament is a disloyal member" of the YMA and MFGB. He appealed finally to the miners to oppose "the men who have deliberately come into your midst to try and kill your power and influence both in politics and combination". ${ }^{73}$

The letter was followed by a hard and bitter campaign. Curran seems, from those of his speeches which the press reported, to have concentrated on issues, but personalities were freely engaged in both by the Lib-Lab leaders and by Keir Hardie in the Labour Leader. Pickard, warming to his task, urged the miners in a speech at Wombwell to drive ILP members out of the union. While opposing violence, he declared that if YMA members could spot ILP'ers they should "treat them as they treated non-unionist miners on the pit bank". ${ }^{74}$ This was not an ile threat. Tom Taylor, the Yorkshire miner who had been in 1896-97 a paid organiser for the ILP, was a prominent supporter of Curran during the campaign. At the end of 1897 he wrote to the Labour Leader, saying that he had received a letter refusing him membership of a branch of the YMA. The letter stated: "The committee object to you on account of you being a member of the I.L.P."75

The ILP put up a very strong fight. It held, according to one estimate, about 200 meetings, a similar number to the Liberals and more than the Conservatives; as the election drew to a close a dozen or more were held in an evening. ${ }^{76}$ Many of the leading figures of the ILP came to speak for Curran. Among them were Hardie (who was in overall command of strategy and expenditure) and Tom Mann; Dr and Mrs Pankhurst; Joseph Burgess, Jim Connell and Robert Blatchford, the Socialist journalists; the young and talented speaker Enid Stacy; and trade unionists, who included Tom McCarthy and James Sexton of the dockers and Robert Smillie, president of the Scottish miners and the only prominent miners' leader to take Curran's part. Will Thorne and the future Labour cabinet minister J. R. Clynes were among the colleagues in the gasworkers' union who spoke for Curran. He was also supported by a number of Barnsley trade unionists, including the checkweighman and YMA branch president of the

73 S\&RI, YP and other papers, 27 September 1897. The Wakefield Free Press, with which Pickard was on close terms, printed the letter two days earlier.

$74 \mathrm{BC}$ and $\mathrm{BI}, 23$ October 1897.

75 LL, 25 December 1897 and 1 January 1898; ILP, NAC minutes, 3 January 1898.

76 YP, 15 October 1897; Morning Post, 27 October; S\&RI, 29 October. Lodge's Barnsley \& District Almanack, op. cit., estimated that between 500 and 600 meetings were held during the campaign. 
Houghton Main Colliery. Messages of support and branch resolutions came from trade unions, trades councils and Socialist bodies all over the country, among whom were dissident Yorkshire miners in South Kirkby and Rothwell led by James Walsh and Willie Lunn, and groups of miners in Lancashire and Staffordshire. (Any inclination on the part of George Barnes, secretary of the Amalgamated Society of Engineers and an ILP member, to assist the party was presumably stifled by Pickard's threat to end the generous financial contributions of the YMA to the locked-out engineers after a group of Leeds engineers had criticised his support for Walton.) ${ }^{77}$ However, excellent speakers and enthusiastic meetings were not enough. The ILP lacked party organisation and manpower for canvassing, and was forced to rely mainly on meetings and literature, including five thousand pamphlets. The Barnsley Independent pointed out that meetings could not substitute for good local organisation. Keir Hardie's meetings at the Bradford by-election of 1896 had been "successful almost beyond description", the paper commented, but Hardie had finished a poor third. ${ }^{78}$

Curran was not always well received. It may have been the case that he was more popular early in the campaign than later, when the telling weight of the YMA leaders had been fully brought to bear. The story has often been told of how Curran was stoned out of Wombwell, which gloried in the title of "the most Radical district in the whole of Yorkshire". Yet this story was not reported by the contemporary press and seems first to have been told by Keir Hardie in a pamphlet published in $1909 .{ }^{79}$ It was not a question of the press being too decorous to print such news, for the stoning attack upon the Conservative candidate in the East Denbighshire byelection in September 1897 was widely reported. (One of the stones weighed three pounds. ${ }^{80}$ Curran was certainly heckled in Wombwell, and some of his meetings were reported as being "very lively" and "somewhat rowdy", though others were clearly successful. ${ }^{81} \mathrm{He}$ returned to Wombwell again and again up to election day, as indeed he had to do if he was not, by

77 BI, 16 October 1897.

78 Ibid., 9 October; Pall Mall Gazette, 24 September; Sheffield Daily Telegraph, 25 September; YP, 2 October; ILP, NAC minutes, 8 April 1898.

79 Wombwell's reputation was so described by the Daily News, 24 September 1897. Hardie's recollection of stone-throwing, which merely stated: "We were stoned by the miners", was recorded in his pamphlet The I.L.P. and All About It [1909], p. 11. Subsequent writers have followed Hardie or the somewhat fuller but undocumented account by Arnot, The Miners, p. 302.

80 Evening Standard, 23 September 1897; Echo, 23 September; YP. 24 September.

81 BC, 9 and 23 October 1897; YP, 6 and 15 October; Sheffield Daily Telegraph, 19, 20, 22, 26 and 27 October; S\&RI, 15 and 20 October. 
ignoring the constituency's second largest town, to give up the fight. Apart from a trap accident which caused Curran to cancel his speaking engagements for a day, the only injury his forces seem to have sustained was on election day, when he toured the constituency accompanied by a party which included Tom McCarthy and Enid Stacy. "Nothing occurred in the way of serious disorder [. . . ] at any point", the Leeds Mercury reported, but a few of the ILP entourage "found themselves occasionally obliged to dodge the unnecessary, if not altogether harmless, sods which were shied at them". 82

Hostile receptions did not cause the ILP to moderate their charges against Walton. They consistently asserted that he was a bad employer, and as a late move in the campaign they plastered the constituency with allegations that he had victimised many miners over the past decade in his Durham pits. Although the ILP claims were denied by John Wilson, secretary of the Durham Miners' Association and himself a Lib-Lab MP, in a last-minute intervention, the evidence of victimisation produced by Hardie in the Labour Leader certainly seems convincing. The ILP later claimed that Wilson's intervention cost Curran a thousand votes. ${ }^{83}$ Curran, on the other hand, was also under personal attack. He was accused of having deserted his wife, of frequently dining with Blyth, in a Catholic area of being an Orangeman, and in Protestant Wombwell of being a Catholic. ${ }^{84}$

The ILP was probably misled at the start of the campaign by the support of the Barnsley Trades Council. It was also misled by miners' strikes in and near the constituency, which it thought would persuade miners to desert their leaders on election day. Willie Lunn, leading a strike at Middleton Colliery, near Rothwell, told a meeting that forty collieries were supplying Middleton with coal. "Mr. Walton was a similar man to those who were supplying the coal, and was not fit to represent working men." 85 More relevant to the election because nearer to Barnsley was the recent strike at the South Kirkby pit, led by James Walsh, Pickard's constant antagonist. South Kirkby lay just outside the constituency, but many of its miners lived at Hemsworth and Kinsley, which were within its boundaries. This had been a long and bitter strike without union backing, involving a thousand miners and prison sentences for a number of men charged with breach

82 LM, 29 October 1897.

${ }^{83}$ I.L.P. News, October 1897; LL, 9 and 23 October, 6 November; YP, 27 and 30 October.

84 Pall Mall Gazette, 25 October 1897; Sheffield Daily Telegraph, 27 October; LL, 6 November.

85 S\&RI, 28 September 1897; BI, 2 October. 
of contract. The result was a wide measure of support for the ILP in Hemsworth and Kinsley, and this was the one district where Walton found difficulty on several occasions in gaining a hearing. ${ }^{86}$ But these strikes and periodic grumblings of protest against the leadership of Pickard and Cowey were not enough to seduce the miners from the traditional appeal of Radicalism.

Shrewd observers correctly predicted the outcome. Montagu Blatchford, writing in the Clarion before the result was known, declared: " 1,000 votes given for Pete Curran will be a splendid testimony to the energy and ability with which the battle has been fought, though it will look like a miserable failure to the thoughtless people who do not know what money, influence, and misrepresentation a dozen poor men have had unaided to contend against." 87 Blatchford's statement was not only a good prediction but a good epitaph. The result was as follows:

Walton, Liberal $\quad 6,744$

\section{Curran, ILP 1,091}

Blyth, Conservative $\quad 3,454$

The Liberal press noted jubilantly that the Liberal vote was almost the same as in the General Election of 1895, while the Conservative and ILP votes nearly equalled the previous Conservative vote. This appeared to justify their assertions that the ILP's appeal was chiefly to Conservative voters rather than to genuine Radicals or trade unionists. Nor did the Liberal press forget that the real victor was Pickard and that the new MP was an employer. The Daily News wrote: "It is pleasant to observe [. . .] that miners have rallied so staunchly to the support of a coalowner. [. . .] Much of the credit [...] is due to Mr. Pickard." From the Conservative side the Sheffield Daily Telegraph called Pickard "the AtLas upon whose shoulders this mighty majority is borne". 88

The magnitude of the defeat marked a low ebb for the ILP. Hardie wrote to his friend David Lowe soon after the election: "Barnsley, altogether, is the worst thing we have yet done", and the I.L.P. News admitted the need to bear with "patience and faith the rejection and scorn of the electors of Barnsley", though it pointed in compensation to ILP gains in the municipal elections which closely followed the by-election. ${ }^{89}$ Party finances suffered

86 YP, 19 August, 1 and 21 October 1897; BI, 2 October; Pall Mall Gazette, 16 October; Manchester Guardian, 27 October.

87 Clarion, 30 October 1897. The Times correspondent also felt that Curran would win "something like a thousand votes" (23 October).

88 Daily News and Sheffield Daily Telegraph, 30 October 1897.

89 David Lowe, From Pit to Parliament (London, 1923), p. 117; I.L.P. News, November 1897. 
severely. Hardie had originally appealed for $£ 300$ and the ILP's National Administrative Council had authorised the expenditure of $£ 350$. But the total cost of the election came to $£ 5285 / 5 \mathrm{~d}$, of which nearly $£ 450$ was paid from central ILP funds, including the heavy drain of $£ 13612 / 2 \mathrm{~d}$ for the ILP's share of official election expenses. Queries were raised on the Council about the wisdom of some items of expenditure, and Ramsay MacDonald undertook an examination of the accounts, which concluded that some money had been unwisely spent upon hotel bills and other expenses. The length of the campaign also played an important part in increasing its cost. Only $£ 171$ was donated to central funds for the Barnsley fight, and the discrepancy between income and expenditure more than accounts for the deficit of $£ 1674 /$ - in the party accounts during the year ended 28 February 1898. A $£ 400$ overdraft had to be negotiated with the Bradford Old Bank and guaranteed by some of the party's leading members, including Hardie, Mann and MacDonald. As a result of the financial setback, the ILP was unable to fight any further by-elections before the General Election of $1900 .^{90}$

The party made what it could of Curran's thousand supporters. In the Labour Leader, the I.L.P. News and the annual report brave words were printed about the impact of the campaign on the Yorkshire miners, and Curran himself wrote: "We are defeated, but not disgraced; and the results of our campaign will be heard of in future in this hitherto untouched part of Yorkshire." ${ }^{11}$ Hardie at year's end claimed that a third of the members of the YMA belonged to the ILP, an astonishingly inaccurate claim, for the paid-up membership of the entire party was only 8,632 , while the membership of the YMA exceeded 50,000. ${ }^{92}$ However, real if temporary progress was made in the Barnsley division, for new branches of the party were formed and membership in the constituency rose from 60 in 1897 to 97 in $1898 .{ }^{93}$

The most important lesson which the ILP leaders drew from the campaign was that only by working with, rather than against trade unions

${ }^{90}$ LL, 2 October and 4 December 1897; 8 January 1898; ILP, NAC minutes, 9 October 1897, 8 January, 26 February and 8 April 1898; ILP, Annual Conference Report, 1898. pp. $19,21$.

${ }_{91}$ LL, 6 November 1897; I.L.P. News, November; ILP, Annual Conference Report, 1898, p. 11.

${ }_{92}$ LL, 25 December; Pelling, The Origins of the Labour Party, op. cit., p. 229.

93 LL, 20 and 27 November 1897; ILP, Annual Conference Report, 1898, p. I. After 1898 no Barnsley delegates attended the annual conference until 1903, but party records suggest that the branch continued to exist with reduced numbers. Hemsworth also had an active branch early in the new century. Annual Conference Reports; Frank Bealey and Henry Pelling, Labour and Politics 1900-1906 (London, 1958), p. 223. 
could real progress be made. Jim Connell wrote immediately after the election in the Labour Leader:

Nearly all the organised workers in the division are miners, and the miners' organisation was opposed to us. Mistakenly, wrongly, wickedly, if you please; but still it was opposed to us. [...] If the Yorkshire Miners' Association were with us, the result would be just as startling the other way. If we are to succeed, the trade unions of this country must be officered with Socialists. In the present stage of development the average Britisher cannot rise above the trade-union level. Let our aim be to win the trade unions for Socialism. ${ }^{94}$

In a sense Connell's final sentence did no more than state existing party policy. But the implication of his words, and the new policy which the ILP was to follow, was the formation of an alliance between Socialists and the non-Socialist unions. This was an alliance not easily brought about. Hardie did not fully accept the idea until the end of $1898 . .^{95}$ On the union side acceptance was slower still. When it did emerge, this labour alliance meant the replacement of Lib-Labism not by Socialism but by Labourism, which in its early-twentieth-century context was to revolve around the conviction that working men needed their own political party rather than one dominated by other social classes. Labourism was to mean little change of programme or ideology; in particular it rejected the demand that a working-class party should be based on belief in class struggle. ${ }^{96}$ Moreover, it should be noted that the shift to Labourism was not encouraged by the Barnsley campaign and election result. The YMA leaders were naturally jubilant at the result and their position became even stronger than before. It was not they or their rank and file who changed their position after the election. It was the ILP. And the adoption of the new line was made easier by the unsystematic, untheoretical nature of the ILP's Socialism. ${ }^{97}$

94 LL, 6 November 1897.

95 Morgan, Keir Hardie, op. cit., pp. 94-98.

96 Henry Pelling, Popular Politics and Society in Late Victorian Britain (London, 1968), ch. 6, esp. p. 118; Ross McKibbin, The Evolution of the Labour Party 1910-1924 (London, 1974), pp. xiv-xv, 70-71. For fuller discussions of Labourism see Saville, "The Ideology of Labourism", loc. cit.; David Coates, The Labour Party and the Struggle for Socialism (London, 1975), pp. 136-44; and Tom Forester, The Labour Party and the Working Class (London, 1976), pp. 31-42.

97 J. Keir Hardie and J. R. MacDonald, "The Independent Labour Party's Programme", in: Nineteenth Century, XLV (1899), pp. 20-38. See also D. W. Crowley, "The Origins of the Revolt of the British Labour Movement from Liberalism 1875-1906" (London University Ph.D. thesis, 1952), abstract and pp. 664-68; Fred Reid, "Keir Hardie \& the Origins of the Labour Party", in: People for the People, ed. by David Rubinstein (London, 1973), pp. 162, 164, 166-67; Morgan, Keir Hatdie, ch. X; and Robert Gray's perceptive discussion in The Labour Aristocracy in Victorian Edinburgh (Oxford, 1976), chs 9 and 10. 
After the turn of the century advocates of a working-class political party made considerable progress among the Yorkshire miners. This was not primarily due to increased support for Socialism, though increased support was clearly evident, nor to reaction against the class collaboration displayed in Barnsley between miners and a mine-owner. Rather, progress came because of important new developments. Bitter and prolonged strikes in the Yorkshire coalfield beginning in 1902 resulted in expensive legal action and loss of membership. The effect of the strikes was to drive a wedge between leaders and members, and to convince many miners that a new type of leadership and new policies were necessary. Moreover, the four principal YMA leaders died in 1903-05, three of them within a two-month period in 1903-04, and after their death the union was never again dominated by forceful leaders wholly committed to Liberal-Labour cooperation. ${ }^{98}$

Numerous events early in the new century demonstrated the growth of a new spirit among the Yorkshire miners. There is space here only to point to a few of them. Significant demonstrations of support for Hardie took place at the Yorkshire miners' gala in 1904, and, speaking at Hemsworth in October 1905 for the first time since 1897, Hardie commented on the change which had "come over the tone and temper of the people". Seven ILP branches were formed in the Yorkshire coalfield within a few weeks in 1904. In 1906 the Yorkshire miners voted by 17,389 to 12,730 in favour of affiliation to the Labour Party, although there was a majority against this move in the mfgb as a whole. Yorkshire had abandoned its position as the most faithfully Lib-Lab of all the Federation's constituent bodies. The Wombwell area was looked upon by 1907 as a Socialist stronghold in the Yorkshire coalfield, and Ramsay MacDonald was promised "the biggest crowd of miners you ever spoke to" if he would pay it a visit. Willie Lunn stood at a by-election at Holmfirth in 1912 as a Labour candidate, and although he was defeated and failed to secure the support of many miners, his candidacy marked the end of the long electoral alliance between the Liberals and the YMA. But in Barnsley itself, despite an incipient move in favour of Herbert Smith in 1905, no Labour candidate was put up against Walton. The seat did not fall to Labour until Walton retired in 1922, his

98 Neville, "The Yorkshire Miners", chs V and VI; id., "In the wake of Taff Vale: The Denaby and Cadeby miners' strike and conspiracy case, 1902-06", in: Studies in the Yorkshire Coal Industry, ed. by J. Benson and R. G. Neville (Manchester, 1976), ch. 7; Duffy, "The Growth of Trade Unionism", pp. 699-708; Bealey and Pelling, Labour and Politics, op. cit., pp. 223-25. 
successor being the miner John Potts, who had supported him in $1897 . .^{99}$

The Barnsley by-election demonstrated the chequered progress of the ILP in the 1890's. It had considerable success as a propagandist body, but it could not convert benevolent general support in to votes. Electoral progress meant an alliance with the unions at the expense of Socialist ideology. The Labour Party, the result of this alliance, was inevitably dominated by the numbers and money of the unions, rather than the Socialist zeal of the ILP. Thus the achievement of the ILP was not to convert the working class to Socialism, as it had hoped and intended to do, but to play an important part in detaching the unions from their Lib-Lab past on behalf of a Labourist future. If this was not what Hardie, Mann, Curran and the others had intended, it was nonetheless an achievement of considerable magnitude.

99 LL, 7 October 1904, 8 September, 13 and 20 October 1905; Bealey and Pelling, Labour and Politics, pp. 222-27; Gregory, The Miners, pp. 104-19. Potts had worked with the ILP against the YMA leadership and Walton as early as 1905. 